\title{
PROTECTION OF EMPLOYEES IN INSOLVENCY PROCEEDINGS
}

Laila Kelmere ${ }^{1}$, PhD student/lecturer

${ }^{1}$ Latvia University of Life Sciences and Technologies

\begin{abstract}
When an enterprise becomes insolvent, it affects the partners (suppliers) of the company, the State and has a significant impact on the employees. The issue of the protection of workers' rights is one of the most important aspects in situations where the employer is declared insolvent. The country can develop its own employee protection system in case of company's insolvency. In this article, based on the statistical data for the period 2003 - 2019, the author analyses the situation in Latvia. The aim of the study is to analyse the existing employee protection mechanism in Latvia, which the State implements with the help of state entrepreneurial risk fee. Two ways of protecting the rights of employees or satisfying claims are distinguished: a privilege system and a guarantee system. Latvia chooses the guarantee system. In this article, based on the statistical data obtained, it is proved that the model chosen by Latvia is financially successful although creates a negligible burden for entrepreneurs, and its benefits are significant because, in line with the situation of Latvia, sufficient financial resources are accumulated each year and employees' claims are covered to a certain amount according to regulations in enactments, as well as the Income Tax and Mandatory State Social Insurance Contributions are paid from these requirements covered by the guarantee fund. The author considers that the State may act as an intermediary or insurer in the insolvency situations of an undertaking in order to protect employees and, in particular, the State budget from covering unforeseeable costs.
\end{abstract}

Key words: employee entitlement, employee's protection, insolvency, state fee.

JEL code: E24, G32, G38, H25, H71

\section{Introduction}

The author examines the role of the state in protecting employees' interests in insolvency proceedings. By means of tax instruments such as the State fee, the State can act as an insurer, as an intermediary, to accrue funds to be paid to employees of insolvent companies in order to provide financial revenue for the work done from the insolvent employer and to reduce the potential burden on the State budget.

The aim of the study is to analyse the existing employee protection mechanism in Latvia, which the State implements with the help of state entrepreneurial risk fee.

The topic is actual because employers' insolvency affects the financial revenues of certain employees, the employer can no longer pay the salary earned in the event of insolvency, which further affects the fact that the person remains without work and financial resources. If the worker does not have sufficient financial resources, he/she is unable to provide oneself and thus is seeking State aid. Currently, there is also a kind of crisis situation due to THE COVID-19 virus, which will have a significant impact on the business environment at the author's discretion and can contribute to an increase in company insolvency claims over the foreseeable period of time. It is therefore important to assess whether the existing employee protection system justifies itself in the context of the employer's insolvency proceedings.

Based on the aim, the following research tasks were set: (1) to analyse the ways in which employees' claims are met; (2) to analyse the size of the state entrepreneurial risk fee and the amount of revenue in the State budget; (3) to collect and analyse the revenues and costs of the employee claims guarantee fund.

The following qualitative and quantitative methods were employed: the monographic method in examining, assessing and analysing literature and legal enactments, selecting only the information

\footnotetext{
${ }^{1}$ Laila Kelmere. E-mail address: laila.kelmere@llu.Iv Tel: +371 29366193
} 
related to the present research, describing findings and interpretations; statistical methods, i.e. statistical observation, compilation and grouping of information, calculation of statistical data, analysis of causal relationships and data generalisation; logical analysis and synthesis. The graphic method was employed to show the relationships identified and their nature and form. The logical construction method was used in analysing results and making judgements.

\section{Research results and discussion}

When an enterprise terminates its activities using the instruments of insolvency proceedings, it affects not only the partners (suppliers) of the commercial company, the State, but has a significant impact on the projected financial revenues of each employee for the work done.

The issue of the protection of workers' rights is one of the most important cases where their employer is declared insolvent. In such a situation, the employer has not fulfilled his/her commitment to the employee - has not paid the remuneration and other payments due to the employee for the work done.

Mucciarelli (2017) indicates when an employer becomes insolvent, employees' claims for unpaid wages and contributions may be protected through statutory priorities, social security schemes, or a combination of both. Analysing social security schemes in France, Germany, and the United Kingdom, Mucciarelli concluded, while France protects employees through both a statutory priority and a social security scheme, Germany and the United Kingdom have progressively reduced employment protection over the last forty years. An important note is that a cumulative application of employee priorities and insurance schemes is not necessarily redundant. (Mucciarelli, 2017).

But not every country has developed special security for employees in insolvency cases. Juris Y. Karaleu indicates the guarantee funds which allow to fully or partially cover the debts to the employees do not exist in Belarus. In Belarus debtor's employees become one of the participants of the relations associated with the insolvency (Karaleu, 2016).

Christopher M. Hughes (2000) indicates that a series of well-publicized corporate collapses have focused the minds of policymakers, business representatives and academics on the problem of how best to protect the entitlements owed to employees of a failed enterprise. Australia analysed a number of options for creating financial support and protecting employees in the event of employer insolvency, among which was to create trust funds or compulsory insurance. Trust funds - was a straightforward model requiring employers to make monthly contributions to cover the full cost of all accrued entitlements. Compulsory insurance proposal was for superannuation funds to administer the service, funded by a $0.1 \%$ increase to the Superannuation Guarantee Levy (old-age pension guarantee fee). Levies are payable by the employer, except in the case of small employers, whose contributions are to be made by the Government. The Employee Entitlement Support Scheme was formally selected as the preferred payment model. Insurance was rejected primarily because of the costs it would impose on business, especially on well-performing companies that already made adequate provisions for entitlements. The government did not want to make these firms subsidize poorly performing or unscrupulous employers (Hughes, 2000).

Two ways of protecting the rights of employees or satisfying claims are distinguished:

1) privilege system;

2) guarantee system (Budget and Finance (Taxation) Committee, 2000). 


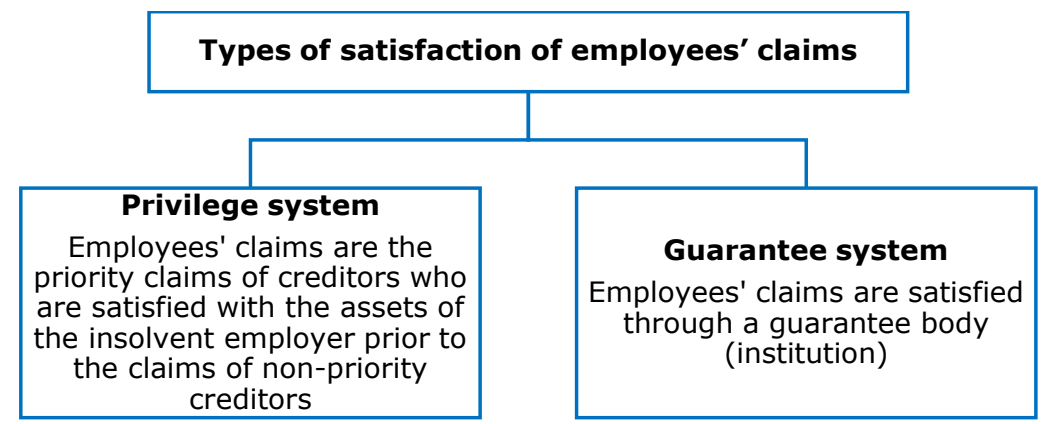

Source: author's construction based on Budget and Finance (Taxation) Committee, 2000

Fig. 1. Types of satisfaction of employees' claims

Until Latvia's accession to the EU, Latvia used a system of privileges to satisfy employees' claims in the event of insolvency, i.e. employees' claims have been identified as priority creditors' claims, which are satisfied with the assets of the insolvent employer prior to covering non-priority creditors' claims. One of the main shortcomings is the time period during which a worker can be paid and the situation of becoming vulnerable, especially at a time when there is a crisis, is not an opportunity to find a new job quickly in order to generate income.

With the guarantee system, the time period during which the employee receives the payment due to him is reduced. Within the framework of the guarantee system, the claims of employees are satisfied through the guarantee body, such as Insolvency Control Service (ICS), which ensures the employees' claims within a sufficiently short period of time, thereby ensuring the protection of employees in the event of insolvency of the employer in accordance with the procedures and to the extent specified in the regulatory enactments.

The EU, by Council Directive 80/987/EEC on the approximation of the laws of the Member States relating to the protection of employees in the event of insolvency of their employer, adopted on 20 October 1980, required EU Member States to provide for the protection of employees in the event of the insolvency of their employer, in particular in order to guarantee that their claims are satisfied in respect of remuneration. consideration of the need to balance economic and social development in the Community (Council Directive 80/987/EEC, 1980).

Latvia needed to introduce Council Directive 80/987/EEC at the time of accession. According to the Latvian National Programme for Integration, the time of implementation of the EU directive was set on 31 December 1999 and was one of the reasons why the Law "On Protection of Employees in case of Insolvency of Employer" was drafted (Annotation of Law "On Protection...", 2000).

Although the author of the draft law points out that the introduction of this law may have a negative impact on the development of the economy, as employers' costs are increased, which increases production costs and, consequently, possible exports and the competitiveness of goods in the external market (Budget and Finance (Taxation) Committee, 2000), the author considers that such a statement is not correct in addition, because the costs to the employer for ensuring protection in the employer's insolvency proceedings are small and do not significantly increase the cost of production (Table 1).

The Law "On Protection of Employees in case of Insolvency of Employer" entered into force on 1 January 2003 and, at this point, employers - companies, companies - are also obliged to pay the State entrepreneurial risk fee.

The author examined the regulatory framework and summarized the amount of the risk fee and the percentage of the fee to be paid to the employee claims guarantee fund (Table 1, Table 2). 
Table 1

State entrepreneurial risk fee amount in Latvia, 2003-2019

\begin{tabular}{|c|c|c|}
\hline Period, year & $\begin{array}{c}\text { Amount of the risk fee } \\
\text { during the reporting } \\
\text { month for each } \\
\text { employee, EUR }\end{array}$ & $\begin{array}{c}\text { Chain } \\
\text { growth } \\
\text { rate, \% }\end{array}$ \\
\hline 2003 & 1.07 & - \\
\hline 2004 & 0.50 & $-53.3 \%$ \\
\hline 2005 & 0.50 & $0 \%$ \\
\hline 2006 & 0.36 & $-28.0 \%$ \\
\hline $2007-2019$ & 0.36 & $0 \%$ \\
\hline
\end{tabular}

Source: author's calculations based on Cabinet of Ministers Regulations, 2002-2018

Latvia chose the model of setting up an employee guarantee fund in which the employer makes contributions and as shown in the figure, initially the amount of the fee was more than 1 EUR per employee (Table 1). In 2003, this levy was reduced by $53.3 \%$ and, in view of the current situation and contributions to this fund, another reduction in the amount of the levy took place in 2006 - this time by $28 \%$ and starting in 2007, the fee in Latvia amounts to 0.36 EUR, which has remained at this level until now.

Data for the share of the State entrepreneurial risk fee to be transferred to the employee claims guarantee fund in Latvia compiled in Table 2.

Table 2

The share of the State entrepreneurial risk fee to be transferred
to the employee claims guarantee fund in Latvia, 2003-2019

\begin{tabular}{|c|c|c|c|}
\hline $\begin{array}{c}\text { Period, } \\
\text { year }\end{array}$ & $\begin{array}{c}\text { Amount to be } \\
\text { transferred to the } \\
\text { employee claims } \\
\text { guarantee fund in \% } \\
\text { or EUR of the total } \\
\text { amount of revenue } \\
\text { from the State fee }\end{array}$ & $\begin{array}{c}\text { Amount } \\
\text { in EUR }\end{array}$ & $\begin{array}{c}\text { Chain growth } \\
\text { rate, \% }\end{array}$ \\
\hline 2003 & $75 \%$ & 5788540.25 & - \\
\hline 2004 & $52 \%$ & 2471975.50 & $-57.30 \%$ \\
\hline 2005 & $43 \%$ & 1889881.56 & $-23.55 \%$ \\
\hline 2006 & $86194.73 €$ & 86194.73 & $-95.44 \%$ \\
\hline 2007 & $303467.25 €$ & 303467.25 & $252.07 \%$ \\
\hline 2008 & $548815.89 €$ & 548815.89 & $80.85 \%$ \\
\hline 2009 & $53 \%$ & 832062.86 & $51.61 \%$ \\
\hline 2010 & $70 \%-89 \%$ & 2195580.84 & $163.87 \%$ \\
\hline 2011 & $78 \%$ & 2195284.89 & $-0.01 \%$ \\
\hline 2012 & $82 \%$ & 2368407.12 & $7.89 \%$ \\
\hline 2013 & $85 \%$ & 2579773.79 & $8.92 \%$ \\
\hline 2014 & $89 \%$ & 2726824.80 & $5.70 \%$ \\
\hline 2015 & $92 \%$ & 2771876.08 & $1.65 \%$ \\
\hline 2016 & $96 \%$ & 2807069.08 & $1.27 \%$ \\
\hline 2017 & $68 \%-100 \%$ & 2584004.56 & $-7.95 \%$ \\
\hline 2018 & $57 \%$ & 1809562.14 & $-29.97 \%$ \\
\hline 2019 & $63.5 \%$ & 2110503.59 & $16.63 \%$ \\
\hline
\end{tabular}

Source: author's calculations based on Cabinet of Ministers Regulations, 2002-2018, and on the author's special request of the data from Insolvency Control Service

The author concludes that at a time when the amount to be transferred to the employee claims guarantee fund was determined in \% from collected fee, the contributions in an amount of EUR was 
higher than in those periods, such as 2006-2008, when the amount of the contribution was determined as a special amount in EUR.

It is the duty to calculate the State entrepreneurial risk fee to any employer who may be declared into insolvency proceedings in accordance with the Law on Insolvency, as employees with whom employment legal relationships have been established in accordance with the provisions of the Labour Law.

The employer shall pay the State entrepreneurial risk fee for each employee in the amount specified in regulatory enactments for each month in which the employment relationship with the employee has existed.

When analysing the regulatory framework, the author concludes that it has had and continues to have a positive impact on economic development and on the state budget, since:

1) a fund for employee claims guarantees has been set up, with the largest amount of funds being paid by employers who have a potential insolvency process and the State has, in this case, established a kind of insurance system that works for workers and also for the benefit of the State, as the State does not need to find additional resources from other budget resources in order to ensure the protection of employees;

2) such minimum payment shall be easily realized and paid to employers;

3) an improved system of employee protection has been established, which does not impair the situation of other creditors in insolvency proceedings but has a positive impact on the financial situation of the employees of the insolvent employer concerned and creates a sense of security and does not create social tensions in society.

When introducing a system of guarantees to satisfy employees' claims, the State established Insolvency Control Service.

The Insolvency Control Service was established on 16 January 2002 with a view to implementing the State insolvency policy, ensuring the protection of public and public interests in order to mitigate the adverse social consequences of the insolvency of companies and companies (Insolvency Control Service).

The Insolvency Control Service is the holder and manager of the employee claims guarantee fund. Resources of the employee claims guarantee fund shall consist of:

1) the part of the entrepreneurship risk State duty (Table 1, Table 2);

2) gifts and donations;

3) amounts recovered by insolvency administrators (Parliament of the Republic of Latvia, 2001).

For research purposes, in order for the author to confirm her view that the introduction of a risk charge is a successful solution which has undermined social tension and contributed to protecting employees in the event of insolvency of their employers, the Insolvency Control Service provided statistics, at the author's request, in an aggregated manner on the revenue and costs of the employee claims guarantee fund (Table 3, Figure 2).

Although the employee claims guarantee may consist of three different revenues, the author of an analysis of the revenue structure of this fund concludes that, between 2003 and 2019, $89 \%$ of the proceeds were a part of the risk fee, $11 \%$ of the sums recovered by administrators, whereas gifts and donations that would have been transferred to the income of that fund were not included (Table 3). 
Revenue of the employee claims guarantee fund, 2003-2019, EUR

\begin{tabular}{|c|c|c|c|c|}
\hline \multirow[b]{2}{*}{$\begin{array}{c}\text { Period, } \\
\text { year }\end{array}$} & \multicolumn{3}{|c|}{ Revenue of the employee claims guarantee fund, EUR } & \multirow[b]{2}{*}{ Total revenue, EUR } \\
\hline & $\begin{array}{l}\text { part of the State } \\
\text { entrepreneurial risk fee }\end{array}$ & $\begin{array}{c}\text { gifts and } \\
\text { donations }\end{array}$ & $\begin{array}{c}\text { amounts recovered } \\
\text { by administrators }\end{array}$ & \\
\hline 2003 & 5788540.25 & 0.00 & 45648.57 & 5834188.82 \\
\hline 2004 & 2471975.50 & 0.00 & 66907.70 & 2538883.20 \\
\hline 2005 & 1889881.56 & 0.00 & 45358.31 & 1935239.87 \\
\hline 2006 & 86194.73 & 0.00 & 436707.82 & 522902.54 \\
\hline 2007 & 303467.25 & 0.00 & 78438.65 & 381905.91 \\
\hline 2008 & 548815.89 & 0.00 & 142876.25 & 691692.14 \\
\hline 2009 & 832062.86 & 0.00 & 52439.94 & 884502.80 \\
\hline 2010 & 2195580.84 & 0.00 & 65497.64 & 2261078.48 \\
\hline 2011 & 2195284.89 & 0.00 & 150151.39 & 2345436.28 \\
\hline 2012 & 2368407.12 & 0.00 & 192666.80 & 2561073.92 \\
\hline 2013 & 2579773.79 & 0.00 & 775533.43 & 3355307.22 \\
\hline 2014 & 2726824.80 & 0.00 & 160772.55 & 2887597.35 \\
\hline 2015 & 2771876.08 & 0.00 & 1440552.11 & 4212428.19 \\
\hline 2016 & 2807069.08 & 0.00 & 161677.84 & 2968746.92 \\
\hline 2017 & 2584004.56 & 0.00 & 192381.14 & 2776385.70 \\
\hline 2018 & 1809562.14 & 0.00 & 225719.62 & 2035281.76 \\
\hline 2019 & 2110503.59 & 0.00 & 296050.83 & 2406554.42 \\
\hline Total, EUR & 36069824.93 & 0.00 & 4529380.60 & 40599205.53 \\
\hline
\end{tabular}

Source: author's calculations based on the author's special request of the data from Insolvency Control Service

During the period 2003-2019, the largest total fund revenue was in 2003, driven by the determined amount of the State entrepreneurial risk fee, which was the highest in the period to be analysed in that year (Table 1, Table 2, Table 3). The smallest revenue was in 2006, 2007 and 2008, when the legislator determined the amount in EUR to be paid to the employee claims guarantee fund. Starting with 2009, the legislator determined the amount of employees' claims be transferred to the guarantee fund as a percentage of the total amount of State entrepreneurial risk fee revenue, which contributed significantly to the fund's revenue. Insolvency administrators may, within the framework of the insolvency proceedings, recover amounts, for example by claiming covered debts or recognizing transactions as invalid, as well as by deducting losses from members of the administrative bodies of the legal person. The data collected show that administrators recover amounts, but overall, in the employee claims fund, they account for only a tenth of the total fund revenue.

In order to assess whether the revenue is sufficient to cover the claims of employees, it is necessary to analyse the costs of this fund for employee claims and related tax payments (Figure 2).

Under the regulatory framework employee claims shall be satisfied from the resources of the employee claims guarantee fund in the following amounts:

1) work remuneration for the last three months of employment legal relationship in the 12 -month period before the occurrence of the insolvency case of the employer;

2) reimbursement for annual paid leave rights to which have been acquired in the 12 -month period before the occurrence of the insolvency case of the employer;

3) reimbursement for other types of paid leave in last three months of employment legal relationship in the last 12-month period before the occurrence of the insolvency case of the employer; 
4) severance pay in the cases laid down in the Labour Law rights to which have been acquired no earlier than in the 12-month period before the occurrence of the insolvency case of the employer;

5) reimbursement for damages for the whole unpaid time period;

6 ) reimbursement for damages for the four subsequent years (Parliament of the Republic of Latvia, 2001).

During the period 2003 to 2019, the insolvency proceedings were declared to 2125 employers who were not covered by liabilities to their employees at the time of the declaration of insolvency, and these claims of employees fulfilled the criteria specified in regulatory enactments in order to be covered by the funds of the employee claims guarantee fund. During the same period, 34725 workers have been paid out of the employee claims guarantee fund for a total amount of EUR 28709 067, including $58 \%$ of that amount paid to the employees' accounts and $41 \%$ transferred to the State budget accounts. From 2013 onwards, compensation paid from this fund to administrators for employees covered by employees' claims of $0.07 \%$.

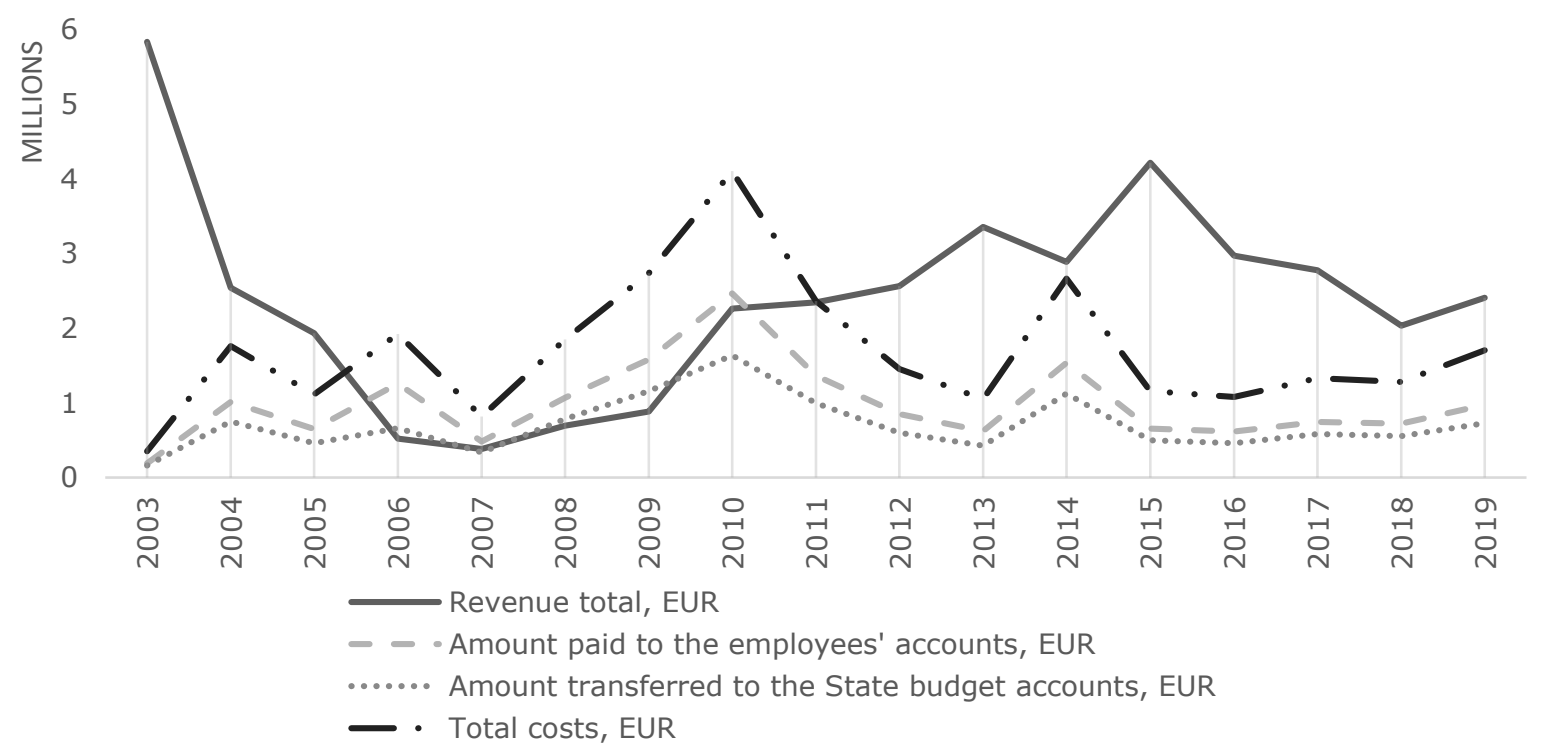

Source: author's calculations based on the author's special request of the data from Insolvency Control Service

Fig. 2. Revenue and expenses of the employee claims guarantee fund, 2003-2019, EUR

In analysing the amount of revenue and expenditure during the analysis period in the employee claims guarantee fund, the author concludes that, on average, the revenue is more than the expenditure showing that, in general, the form of revenue and expenditure planning has justified itself, with the exception of three-year decisions (2006-2008), when it was decided to pay a specific amount rather than to make a contribution as a percentage of those collected risk charges. In addition, the regulatory enactments have periodically imposed limits, including in terms of money, on the amount to be paid from the employee claims guarantee fund, in order to be able to satisfy as many employees' claims as possible during the crisis. Initially and also today, there are conditions on what kind of claims are covered by the fund for employee claims.

Expenditure over revenue was exceeded by six years, during the period 2006-2011, which is explained by deliberate reductions in contributions and the effects of the financial crisis. The growing cost increases coincide with periods when the number of companies with limited liability liquidation has increased. The author has analysed and published the dynamic of insolvency and liquidation of limited liability companies in separate studies and papers. Until 2003, a system of privileges for the satisfaction of employees' claims was operational, but from 2003 the guarantee system began to 
operate, which significantly reduced the time during which a worker could receive a fee for his or her claim to the extent specified by law.

As the author pointed out above, $41 \%$ of the total costs of the employee claims guarantee fund was paid to the State budget accounts during the analysis period. These contributions are directly linked to workers and their social protection (Table 3).

Table 3

\section{Expenses of the employee claims guarantee fund for employees} and State budget, 2003-2019, EUR

\begin{tabular}{|c|c|c|c|c|c|c|}
\hline \multirow[b]{2}{*}{$\begin{array}{l}\text { Period, } \\
\text { year }\end{array}$} & \multirow[b]{2}{*}{$\begin{array}{c}\text { Number } \\
\text { of } \\
\text { insolvent } \\
\text { employers }\end{array}$} & \multirow[b]{2}{*}{$\begin{array}{l}\text { Number of } \\
\text { employees' } \\
\text { claims } \\
\text { (paid) }\end{array}$} & \multirow[b]{2}{*}{$\begin{array}{l}\text { Amount paid } \\
\text { to employee } \\
\text { accounts, EUR }\end{array}$} & \multicolumn{3}{|c|}{ Amount transferred to the State budget accounts } \\
\hline & & & & Total, EUR & $\begin{array}{l}\text { Personal } \\
\text { income tax }\end{array}$ & $\begin{array}{c}\text { Mandatory } \\
\text { State Social } \\
\text { Insurance } \\
\text { Contributions }\end{array}$ \\
\hline 2003 & 15 & 829 & 190107.06 & 161164.42 & 61820.93 & 99343.49 \\
\hline 2004 & 80 & 2791 & 1010700.00 & 751105.57 & 281816.84 & 469288.73 \\
\hline 2005 & 103 & 1497 & 651052.07 & 460703.13 & 180021.74 & 280681.38 \\
\hline 2006 & 95 & 2598 & 1260116.62 & 659656.18 & 257531.26 & 402124.92 \\
\hline 2007 & 60 & 928 & 482492.99 & 335938.61 & 130787.53 & 205151.08 \\
\hline 2008 & 84 & 1029 & 1068397.45 & 781512.34 & 298808.77 & 482703.57 \\
\hline 2009 & 138 & 2015 & 1580837.62 & 1155221.09 & 452332.37 & 702888.71 \\
\hline 2010 & 340 & 5398 & 2465088.42 & 1635760.47 & 621570.17 & 1014190.30 \\
\hline 2011 & 303 & 3870 & 1363771.41 & 996908.10 & 394623.54 & 602284.56 \\
\hline 2012 & 172 & 2158 & 852673.01 & 601575.97 & 247800.24 & 353775.73 \\
\hline 2013 & 128 & 1418 & 621466.20 & 428054.78 & 168626.19 & 259428.59 \\
\hline 2014 & 111 & 3590 & 1539322.59 & 1122806.15 & 442591.64 & 680214.51 \\
\hline 2015 & 108 & 1432 & 656815.17 & 500232.08 & 192160.23 & 308071.85 \\
\hline 2016 & 108 & 1226 & 613451.15 & 460067.42 & 171559.34 & 288508.08 \\
\hline 2017 & 85 & 1425 & 742945.77 & 582292.72 & 221594.21 & 360698.51 \\
\hline 2018 & 83 & 1252 & 720245.75 & 553510.73 & 203520.73 & 349990.00 \\
\hline 2019 & 112 & 1269 & 973943.31 & 729130.70 & 257350.07 & 471780.63 \\
\hline Total: & 2125 & 34725 & 16793426.56 & 11915640.45 & 4584515.80 & 7331124.65 \\
\hline
\end{tabular}

Source: author's calculations based on the data from Insolvency Control Service

By establishing a national tax instrument, the State entrepreneurial risk fee, the State acted as an insurer against uncollected tax payments and without creating an additional burden on the budget of providing financial resources to employees of insolvent companies.

\section{Conclusions, proposals, recommendations}

1) Two ways of protecting the rights of employees or satisfying claims are distinguished: (1) privilege system and (2) guarantee system.

2) Since 2003, the companies in Latvia are obliged to pay the State entrepreneurial risk fee. It is the duty to calculate the State entrepreneurial risk fee of any employer who may be declared into insolvency proceedings in accordance with the Law on Insolvency. The employer shall pay the State entrepreneurial risk fee for each employee in the amount specified in regulatory enactments for each month in which the employment relationship with the employee has existed.

3) Resources of the employee claims guarantee fund shall consist of: the part of the entrepreneurship risk State fee; gifts and donations and amounts recovered by insolvency administrators. From 2003 to $2019,89 \%$ of the proceeds are part of the risk fee, $11 \%$ of the sums recovered by administrators, whereas gifts and donations that would have been transferred to the income of that fund are not included. 
4) Analysing the amount of revenue and expenditure during the analysis period in the employee claims guarantee fund, the author concludes that, on average, the revenue is more than the expenditure showing that, in general, the form of revenue and expenditure planning has justified itself, with the exception of three-year decisions (2006-2008), when it was decided to pay a specific amount rather than to make a contribution as a percentage of those collected risk charges.

5) During the period 2003 to 2019, 34725 workers have been paid a total amount of EUR 28709067 out of the employee claims guarantee fund, including $58 \%$ of that amount paid to the employees' accounts and $41 \%$ transferred to the State budget accounts.

6) By establishing a national tax instrument, the State entrepreneurial risk fee, the State acted as an insurer against uncollected tax payments and without creating an additional burden on the budget of providing financial resources to employees of insolvent companies.

7) The author considers that the amount of the State entrepreneurial risk fee set in recent years at EUR 0.36 per employee per month is sufficient in the current economic situation in the country. Further investment of State entrepreneurial risk fee revenues in the employee claims guarantee fund should be pursued.

\section{Bibliography}

1. Budget and Finance (Taxation) Committee. (2002), Annotation of Law "On Protection of Employees in case of Insolvency of Employer". Retrieved: https://www.saeima.Iv/L_Saeima7/lasa-LP0749_0.htm. Access: 08.02.2020.

2. Cabinet or Ministers (2002-2018). Cabinet Regulation No 608, 600, 10, 850, 721, 849, 1031, 1478, 1212, 901, 700, 1249, 751, 692, 836, 772, 694, "Rules on the State Business Risk fee in 20xx". Retrieved: https://likumi.lv/. Access: 08.02.2020.

3. Council Directive 80/987/EEC of 20 October 1980 on the approximation of the laws of the Member States relating to the protection of employees in the event of the insolvency of their employer (1980). Retrieved: https://eur-lex.europa.eu/eli/dir/1980/987/oj. Access: 02.02.2020.

4. Hughes, C. (2000), Towards Pinstriped Unionism: Protecting Employee Entitlements Through Securitisation. Bond University Falculty of Law. BondLawRw 2; (2000) 12(1) Bond Law Review 7. Retrieved: http://www.austlii.edu.au/au/journals/BondLawRw/2000/2.html\#fn38. Access: 15.04.2020.

5. Insolvency Control Service (s.a.) History. Retrieved: http://mkd.gov.lv/lv/parmums/vesture/. Access: 03.02.2020.

6. Karaley, Y. (2016), Insurance for Handling Employee Entitlements in the Event of Employer Insolvency (Bankruptcy). Nauki o Finansach Financial Sciences, 2016, No 2 (27), doi: 10.15611/nof.2016.2.03. Access: 15.04.2020.

7. Mucciarelli, F.M. (2017), Employee Insolvency Priorities and Employment Protection in France, Germany, and the United Kingdom. Journal of Law and Society, 44: 255-282. doi:10.1111/jols.12025. Access: 15.03.2020.

8. Parliament of the Republic of Latvia (2001). Law "On Protection of Employees in case of Insolvency of Employer". Retrieved: https://likumi.Iv/ta/en/en/id/56944-on-protection-of-employees-in-case-ofinsolvency-of-employer. Access: 03.03.2020. 